Dorota Rynkowska

(Uniwersytet Rzeszowski, Instytut Socjologii)

\title{
Wybrane aspekty jakości życia osób starszych
}

\section{Wstęp}

Starzenie się społeczeństw jest jednym z charakterystycznych zjawisk współczesnego świata. Za bezpośrednie przyczyny starzenia się społeczeństwa należy uznać przeszłe i aktualne trendy pod względem rodności, migracji i umieralności. Celem nowoczesnej polityki społecznej wobec osób starszych jest między innymi próba dbałości o jakość ich życia w poszczególnych fazach starości i skuteczne reagowanie na specyficzne potrzeby seniorów. Na potrzeby niniejszego artykułu odnoszącego się do wybranych aspektów jakości życia osób starszych, termin ten będzie rozumiany jako: „ogół cech i właściwości zróżnicowanych środowiskowo oraz zmieniajacych sie pod wpływem konkretnych warunków i położenia, które decydują o zdolności do zaspokojenia potrzeb, realizacji celów osobistych i funkcjonowania jednostek w czterech poziomach aktywności: fizycznym, materialnym, społecznym i emocjonalno-intelektualnym (Woźniak 2003:16). W badaniach prowadzonych wśród osób starszych wskazuje się, że głównymi czynnikami wpływajaccymi na jakość ich życia są: zdrowie fizyczne, podtrzymywanie relacji rodzinnych i społecznych, brak dyskryminacji, zdolność do aktywnego uczestnictwa w różnych obszarach życia, zabezpieczenie materialne, stosunek społeczeństwa do tej kategorii osób (Frackiewicz 2002; Tobiasz-Adamczyk 2000; Sęk 2001; Halicka, Pędlich 2002; Steuden, Oleś 2005; Lasota 2006; Wolańska 2006).

\section{Prognozy demograficzne}

Zjawisko starzenia się społeczeństwa rodzi konsekwencje, zarówno w ogólnospołecznym rozwoju, jak w sferze zabezpieczenia i bezpieczeństwa socjalnego seniorów. Wzrost długości życia, do którego w znacznym 
stopniu przyczynił się postęp medycyny i rozwój gospodarczy, zwiększył zainteresowanie okresem starości zarówno w aspekcie kulturowym, ekonomicznym, jak i społecznym. Stały wzrost udziału osób starszych w ogólnej liczbie ludności w poszczególnych krajach Europy i świata, jest konsekwencja wydłużania czasu życia przeciętnego człowieka przy jednoczesnym spadku liczby urodzeń (Frąckiewicz 2002:33). Według prognoz demograficznych, na całym świecie utrzymywać się będzie tendencja do dalszego powolnego zwiększania się odsetka osób starszych w społeczeństwach. Silna korelacja pomiędzy średnią długością życia a rozwojem gospodarczym powoduje, że niemal wszystkie kraje Europy przekroczyły próg 70 lat życia, a takie kraje jak Islandia, Szwecja, Francja, Dania, Norwegia, USA, Japonia, Izrael i Kanada przekroczyły próg 75 lat. Wyniki Narodowego Spisu Powszechnego z 2011 r. podaja, że odsetek osób w wieku 60 lat i powyżej sięgał 17\%, a w wieku powyżej 65 lat $13,6 \%$. Następuje stopniowe kontynuowanie tendencji wzrostu liczby osób starszych (w 2011 r. co siódmy mieszkaniec Polski liczył 65 lat i więcej). Łatwo daje się zauważyć, że demograficzne starzenie się społeczeństwa wykazuje tendencje wzrostową. Nie ulegnie ona w ciagu najbliższych dwudziestu lat odwróceniu. Starzenie się społeczeństwa wiąże się z wieloma konsekwencjami społecznymi, medycznymi, kulturowymi i ekonomicznymi. W efekcie odsetek osób starszych w Polsce w wieku 60 lat i powyżej w 2030 r. będzie wynosił 24,7\% (Szatur-Jaworska i in. 2006:154-155). Oznacza to, że zjawisko społecznego starzenia się nabierze rozpędu w drugiej dekadzie tego stulecia. W okresie tym przybędzie $2 \mathrm{mln}$ osób starszych. Stanie się to następstwem wejścia w wiek emerytalny pokolenia powojennego wyżu demograficznego. Starzenie się naszego społeczeństwa będzie nosiło określenie podwójnego starzenia się, bowiem liczebność najstarszych emerytów (powyżej 80 lat) wzrośnie z 0,8\% obecnie do 1,8\% w 2030 r. Wzrost odsetka seniorów w naszym kraju związany jest z kilkoma czynnikami: przede wszystkim spadkiem dzietności i współczynnika płodności kobiet, a także z wydłużającego się czasu trwania życia. Starzenie się społeczeństwa niesie za sobą daleko idące reperkusje ekonomiczne, medyczne i społeczne. Ze względu na kurczaca się grupe ludzi aktywnych zawodowo, możemy spodziewać się zachwiania proporcji pomiędzy pracujacymi a pobierającymi świadczenia społeczne. To z kolei spowoduje poważny wzrost wydatków związanych z emeryturami, zdrowiem i opieką społeczną. Obserwowalną tendencją będzie również rosnacce zapotrzebowanie na usługi pielęgnacyjno-opiekuńcze, zwiększenie interwencji ze strony państwa i profesjonalnych służb społecznych. Ponadto demograficzne starzenie się ludności, dłuższe przeciętne trwanie życia, zapadalność seniorów na wiele chorób, wymusza dofinansowania wielu dyscyplin leczenia 
szpitalnego, rehabilitacyjnego, opiekuńczego. Rozsądna polityka wydatkowania środków w tym zakresie przyczynić się powinna do poprawy sprawności funkcjonalnej seniorów, skracania okresów hospitalizacji, a tym samym do poprawy jakości jego życia, redukując liczbę zgonów (Mielczarek 2010:34).

Analiza struktury społeczno-demograficznej seniorów w naszym kraju powinna być wskazówka dla różnego typu organizacji i instytucji odpowiedzialnych za politykę społeczną i zdrowotna, aby szczególnie zaangażować się $\mathrm{w}$ systemowe działania na rzecz obywateli w wieku podeszłym, stworzenie warunków aktywizujacych w poszczególnych fazach starości, a także ułatwienie podejmowania działalności wolontariackiej na rzecz samych seniorów i pomocy seniorów dla innych potrzebujących. W ramach tego typu działań i funkcjonowania odpowiednich struktur dostosowanych do możliwości osób starszych, możliwe jest zaspakajanie wielu potrzeb tej grupy społecznej. Poprzez uczestnictwo w tak zorganizowanych działaniach, wiele osób starszych zaspokaja potrzebę poczucia bezpieczeństwa czy bycia użytecznym. Taka forma kontaktów stanowi dla nich grupe wsparcia, zaufania, wymianę myśli i doświadczeń, a także pozwala na budowanie pozytywnego obrazu starości, zarówno dla nich samych, jak i społecznego odbioru. Udział w tego typu strukturach mógłby pozwolić seniorom na zachowanie sprawności i aktywności jak najdłużej, oddalając tym samym perspektywę różnych form opieki instytucjonalnej.

\section{Wybrane aspekty jakości życia seniorów}

Zagadnienia jakości życia w przypadku osób starszych wiążą się przede wszystkimi ze stanem ich zdrowia i dobrymi relacjami z rodzina i innymi ludźmi. Starzenie się człowieka łączy się ze stratami w wielu obszarach życia, a ich nakładanie się stanowi o obniżeniu jakości życia. Z tego powodu analiza czynników jakości życia u osób starszych powinna uwzględniać wiele czynników wzajemnie na siebie oddziałujących. Starzenie się ludzi jest zjawiskiem naturalnym i powszechnym, jednak nadal mało poznanym. Starzenie się może przyjmować różne stany i perspektywę. Ludzie starsi stanowią zróżnicowana populację pod wieloma względami. Różnice te wynikaja $\mathrm{z}$ indywidualnych cech osobowościowych, doświadczeń życiowych, warunków zewnętrznych, które wpływają na kształt osobowości i jakości życia seniorów.

Próby określenia jakości życia napotykają na wiele trudności z różnych powodów - u poszczególnych osób jest ona inna, zależy od warunków społecznych i socjalnych, odzwierciedla refleksyjną ocenę własnego 
życia i stopień zadowolenia z życia jako całości poszczególnych sfer (Steuden, Okła 2007:6-7). Termin jest używany zarówno w znaczeniu szerokim, jak i waskim. Jego szerokie rozumienie obejmuje pełne spektrum doświadczeń człowieka i najpełniej odzwierciedla znaczące obszary jego życia. Na podstawie badań empirycznych wyodrębniono kilkanaście takich obszarów: relacje społeczne, psychologiczny dobrostan i zadowolenie, aktywność zawodowa, stanowienie o sobie, autonomia, zdolność dokonywania wyborów, kompetencje osobowe, umiejętność utrzymywania więzi z innymi ludźmi przy równoczesnej zdolności do bycia niezależnym, poczucie bycia we wspólnocie, otrzymywanie wsparcia, zdolność do rozwoju, społeczny status, a także fizyczny i materialny dobrostan (Steuden, Okła, 2007:6).

W ujęciu węższym, które staje się w ostatnich latach coraz bardziej popularne, termin jakości życia odnosi się do populacji osób zdrowych, zróżnicowanych ze względu na wiek, zawód, status społeczny, warunki ekonomiczne, a także osób chorych w różnych grupach klinicznych (osoby chore somatycznie, psychicznie, niepełnosprawne). Większość koncepcji psychologicznych koncentruje się na subiektywnym ujęciu jakości życia, odzwierciedlającym dobrostan psychiczny, można jednak wskazać na jej aspekt obiektywny, możliwy do oceny zewnętrznej. Subiektywny aspekt jakości życia można rozumieć w kategorii stanów psychicznych jednostki, które towarzysza jej w zaspokajaniu potrzeb, realizacji celów i są rezultatem poznawczej oceny relacji, jaka zachodzi między nią a otoczeniem. Ocena ta dotyczy jej własnych osiągnięć i niepowodzeń, a także możliwości spełnienia planów, dążeń i celów życiowych. Określenie poziomu jakości życia konkretnego człowieka wymaga spojrzenia na życie i otoczenie z jego osobistej perspektywy i dokonania oceny poczucia zgodności między jego indywidualnymi potrzebami a zasobami otoczenia. Natomiast aspekt obiektywny jakości życia koncentruje się wokół uwarunkowań społecznych, kulturowych i strukturalnych. W rozważaniach nad jakościa życia i poczuciem satysfakcji życiowej ważne jest stanowisko Havighursta, który podkreśla, powiązanie zadowolenia i satysfakcji życiowej w okresie starości z wcześniejszymi okresami życia: dzieciństwem, młodością i dorosłością. Zgodnie z koncepcja Havighursta zadowolenie z życia decyduje o przystosowaniu i równowadze pomiędzy indywidualnymi potrzebami i oczekiwaniami społecznymi a społecznymi wydarzeniami życiowymi (np. choroba, utrata pracy czy śmierć bliskich). Jakość życia jest zatem ogólną refleksyjną oceną życia (dotyczy takich obszarów, jak: zdrowie, praca, relacje z rodzina, z przyjaciółmi i innymi ludźmi, standard życia) i odzwierciedleniem spostrzeganej przez osobę rozbieżności między jej osiagnięciami a potrzebami i oczekiwaniami (Steuden 2011:165). 
U poszczególnych osób wskaźnik satysfakcji z życia ma charakter stabilny w okresie życia dorosłego, natomiast w okresie starości obniża się.

Liczne teorie obrazujące zjawisko starości wskazuja zgodnie, że proces starzenia się łączy się z obniżeniem zdolności osoby starszej do reagowania na to, co dzieje się w jej otoczeniu, z postępujacymi zmianami w zakresie stanu zdrowia, kondycji psychicznej i fizycznej, zdolności poznawczych oraz wymagań społecznych, politycznych i fizycznych.

\section{Zdrowie a jakość życia}

Jakość życia pozostaje w ścisłym związku ze stanem zdrowia lub stanem sprawności funkcjonalnej. Bez wątpienia na jakość życia ludzi starszych największy wpływ ma zdrowie. Jakość życia uwarunkowana stanem zdrowia określana jest jako możliwy do osiagnięcia optymalny poziom zdolności fizycznych, psychicznych i społecznych (de Walden-Gałuszko 1994:17). Spośród wielu potrzeb człowieka starszego na plan pierwszy wysuwaja się te , które mają związek z zapewnieniem opieki medycznej i usług opiekuńczych. Stan zdrowia i samopoczucie maja ogromną wartość dla seniorów. Częste choroby i większa zapadalność na nie w różnym stopniu dezorganizuja życie osób starszych. Budza uzasadniony lęk o dalszą przyszłość i funkcjonowanie człowieka starego w rodzinie i w społeczeństwie. Można uznać, że wspomniane potrzeby i próby ich zaspokajania stają się najważniejszymi priorytetami osób starszych. Zdrowie człowieka może być rozpatrywane, podobnie jak pojęcie jakości życia, w aspekcie obiektywnym, jak i subiektywnym. W sensie obiektywnym oznacza poprawny rozwój i funkcjonowanie w poszczególnych sferach życia. Natomiast w subiektywnym znaczeniu jest to ocena samopoczucia i możliwości sprawnego funkcjonowania danej osoby. Zaproponowana przez WHO w 1947 r. i obowiąująca do dziś definicja zdrowia, traktuje je jako ogólny dobrostan psychiczny, fizyczny i społeczny, a nie tylko niewystępowanie choroby lub kalectwa. W tym rozumieniu zdrowie określa się w kategoriach subiektywnych jako sytuacje pełnej sprawności psychicznej, fizycznej i społecznej umożliwiajacej człowiekowi pełnienie ról społecznych, a także zdolność adaptacji do zmieniajacych się warunków środowiska (Talarska i in. 2008:18). Podobne podejście w odniesieniu do oceny zdrowia i jakości życia seniorów prezentuje gerontologia społeczna. Jako nauka bada społeczne przyczyny i skutki starzenia się społeczeństw. Zajmuje się osobowością ludzi starszych w rodzinie, ich rolą i miejscem w rodzinie i w społeczeństwie, relacjami z otoczeniem, stosunkiem do biologicznego starzenia się, a także postawami społeczeństwa wobec rodziny. 
Do ważnych zagadnień sytuujących się w gerontologii społecznej zaliczyć można jakość życia ludzi starszych związana z ich zdrowiem fizycznym, warunkami życia i zaspakajaniem ich potrzeb. Ludzie starsi stanowią grupe społeczna, w której problemy zdrowotne, sytuacja rodzinna i warunki materialne mają wpływ na jakość życia seniorów. W socjologii zdrowie jest rozpatrywane w kategoriach uczestnictwa w systemie społecznym, czyli traktowanym jako właściwa zdolność do pełnienia ról społecznych wyznaczonych jej przez proces socjalizacji (Zych 2007:211).

Okres starości jest niejednolity pod względem stanu zdrowia, stopnia samodzielności, sprawności fizycznej i psychicznej. Jakość życia seniorów obniża zły stan ich zdrowia. Zdecydowana większość z nich skarży się na szereg dolegliwości, które sa albo przewlekłymi już schorzeniami (bóle stawów, choroba wrzodowa, choroby układu krążenia czy nowotwory) lub chorobami charakterystycznymi dla wieku starczego (osteoporoza, otyłość, nietrzymanie moczu, choroba Alzheimera, udary mózgu, depresja starcza). Stanowią oni grupe pacjentów wymagających najczęściej stałej specjalistycznej opieki, potrzebujących więcej troski i wsparcia oraz przystosowania struktur służby zdrowia do ich specyficznych potrzeb.

Szczególnie bolesne dla osób starszych staje się obniżenie sprawności zmysłu wzroku i słuchu. Wzrok jak wiadomo ma kluczowe znaczenie w kontroli otoczenia i kontaktach ze światem zewnętrznym. Poczucie jakości życia u osób starszych z zaburzeniami widzenia koreluje z osamotnieniem, lękiem, depresją, zaniżoną samoocena, a także obniżeniem umiejętności społecznych. Pogarszanie się słuchu z kolei stanowi trudności w codziennym funkcjonowaniu (rozmowa, odbiór i przekaz informacji) seniora. Konsekwencja tego staje się poczucie niezrozumienia, osamotnienia, izolacji czy zawstydzenia. Okazuje się, że dla prawidłowego poziomu jakości życia i satysfakcji życiowej osób starszych z zaburzeniami słuchu istotne znaczenie ma jakość relacji z rodzina, osobami bliskimi i dalszym otoczeniem. Poprawa wzroku i słuchu osób starszych poprzez różne działania korekcyjne może przyczyniać się do wzmacniania jakości ich życia i poprawy relacji rodzinnych poprzez aktywne uczestnictwo w sprawach domowych i codziennych (Steuden 2011:48).

Badania dotyczące osób starszych, zarówno zdrowych, jak i chorych wskazuja na dwie podstawowe grupy potrzeb i problemów. Pierwsze z nich odnoszą się do zapewnienia odpowiedniej opieki medycznej, dostępności do specjalistycznego leczenia, a także możliwości niwelowania bólu, który występuje w wielu chorobach przewlekłych. Drugie związane sa z obawą przed następstwami choroby: utratą możliwości samodzielnego egzystowania, potrzeba korzystania z pomocy innych, brakiem 
środków finansowych, zmiana w relacjach rodzinnych i społecznych (Steuden 2011:194). Zdrowie w korelacji z jakością życia według osób starszych polega na dobrym samopoczuciu, które jest rezultatem stabilności fizycznej i psychicznej organizmu oraz współpracy ze środowiskiem społecznym. Zdrowie nie jest ideałem, do którego należy zmierzać, tylko narzędziem usprawniającym satysfakcjonujące funkcjonowanie. Niestety z upływem lat zmniejsza się zdolność człowieka do prawidłowego funkcjonowania w wymiarze fizycznym. W starszym wieku dochodzi do szeregu zmian w poszczególnych narządach. Specyfika wieku starszego jest pojawianie się kilku kategorii chorób i zespołów chorobowych. Stosunkowo powszechnym zjawiskiem wśród seniorów jest występowanie problemów geriatrycznych. Ignorowanie i brak właściwej diagnozy lekarskiej w tego typu schorzeniach prowadzi do uzależnienia osoby starszej od rodziny i osób trzecich, wzrostu nakładów kosztów ponoszonych przez społeczeństwo w związku z rehabilitacją i zapewnieniem właściwej opieki, a także utrwalaniem się w społeczeństwie niekorzystnego stereotypu na temat ludzi starszych. Do najczęściej występujacych problemów geriatrycznych zalicza się: chorobę Alzheimera i inne zespoły otępienne, upadki i zaburzenia lokomocyjne, starcza depresje i zaburzenia snu, zaburzenia funkcjonowania zwieraczy i upośledzenie w pracy narządów zmysłów (Krzyżowski 2004:91-95). Zły stan zdrowia ogranicza w różnym zakresie mobilność osób starszych, zmusza ich do przerwania pracy, utrudnia prowadzenie domu i wykonywanie podstawowych czynności życiowych. Może także być przyczyną ograniczania kontaktów z innymi ludźmi, utrudniać czy wręcz uniemożliwiać aktywny udział w życiu społecznym, kulturalnym. Niekorzystny stan zdrowia zmniejsza możliwość korzystania w sposób aktywny z czasu wolnego, kina, teatru, innych rozrywek. Sprzyja pogarszającemu się samopoczuciu, które w konsekwencji obniża poziom zadowolenia i satysfakcji życiowej seniorów.

Ważna jest również kwestia kondycji psychofizycznej. Często mówi się o całokształcie zmian chorobowych, które od choroby przewlekłej poprzez fizyczna niepełnosprawność, postępujące ograniczenia w codziennym funkcjonowaniu prowadza do utraty dobrostanu psychicznego i obniżenia zdolności funkcjonowania społecznego. Zmiany te moga przekładać się na niskie poczucie jakości życia seniorów. Niedomagania psychiczne występuja z pewnym nasileniem w okresie starczym, ale ich geneza ma miejsce dużo wcześniej. Poważnymi przyczynami ograniczeniami zdrowotnymi ludzi w podeszłym wieku są różnego rodzaju zespoły otępienne. Do najczęściej występujących należy otępienie typu Alzheimera, które obejmuje 60\% zespołów otępiennych w tym okresie życia (Steuden 2011:61). Za najważniejszy czynnik ryzyka zachorowania na tę chorobe uznaje się wiek osoby. Zasadniczym problemem 
w chorobie Alzheimera jest stopniowa utrata pamięci, spowodowana zmianami w mózgu i zanikaniem poszczególnych komórek. Oprócz zaburzeń pamięci występują zaburzenia wyższych czynności korowych: afazja, apraksja i agnozja. Na skutek upośledzenia funkcji pamięci człowiek traci możliwość przeżywania aktualnej rzeczywistości. Pogłębiające się zaburzenia pamięci powoduja zaburzenia rozumienia i mowy. Chory zaczyna mieć trudności w rozumieniu sytuacji społecznych, nazywaniu i rozpoznawaniu znanych osób, przedmiotów, miejsc. Nasilaja się trudności w wykonywaniu codziennych czynności związanych z higiena osobista, dbałością o wygląd zewnętrzny, prowadzeniem gospodarstwa domowego. Oprócz choroby Alzheimera i inne zespołów otępiennych, wśród zaburzenia występujących u osób starszych rozpowszechnione są depresje. Najczęściej rozpoznawane jest obniżenie nastroju, z przeżywaniem smutku i przygnębienia. Do czynników ryzyka pojawienia się symptomów depresyjnych zalicza się przede wszystkim dolegliwości związane $\mathrm{z}$ chorobą przewlekła somatyczna, niską ocenę zdrowia, obniżona zdolność do funkcjonowania psychospołecznego, deficyty wzrokowe i słuchowe, spostrzeganie negatywnych zmian w życiu, a także utrata bliskich osób (Steuden 2011:67). Zarówno depresja, jak i inne choroby somatyczne przyczyniaja się do zaburzeń w codziennym funkcjonowaniu, a jednocześnie sa wskazaniem do korzystania z opieki medycznej. Stan ten wymaga kompleksowego podejścia do chorego seniora, zarówno ze strony najbliższych, jak rozwiązań zdrowotnych ze strony różnych służb pomocowych. Zaburzenia te stanowią poważne obciążenie dla opiekunów, którzy powinni wykazywać się troska i cierpliwością. Z kolei odczuwana niechęć i poczucie braku wsparcia u opiekunów staje sie przyczyną wyczerpania emocjonalnego, zmęczenia fizycznego, zniechęcenia i poczucia bezradności chorego. Zespoły otępienne występujące $\mathrm{z}$ dużym natężeniem $\mathrm{u}$ osób starszych stają się problemem, zarówno medycznym, jak i społecznym. Światowa Organizacja Zdrowia postuluje, aby celem polityki zdrowotnej stawało się kompleksowe wspieranie chorego poprzez eliminowanie stresów, objęcie pomocą i wsparciem poszczególnych dziedzin życia, czyli stanu zdrowia, socjalizacji, rehabilitacji.

Postulatem nowoczesnej opieki nad osobami starszymi stała się troska o ich jakość życia. Jest to również celem zintegrowanej polityki społecznej i zdrowotnej, wzrasta standard opieki medycznej i powstaja wysoko specjalistyczne procedury usług medycznych dla ludzi starszych. Jakość opieki zdrowotnej stanowi jeden z najważniejszych determinantów jakości życia ludzi starszych, chociażby z tego względu, że stan zdrowia wielu z nich jest nie zadowalajacy i pogarsza sie, generujac nowe schorzenia. W strategiach zdrowia publicznego WHO pojawia 
się wielowymiarowe ujęcie zdrowia, ze szczególnym zwróceniem uwagi na takie kwestie, jak: potrzeba subiektywnego odczuwania satysfakcji z życia, aktywne uczestnictwo w życiu rodzinnym i społecznym, wydłużenie oczekiwanego życia bez niepełnosprawności czy poczucie własnej godności (Mielczarek 2010:122). Według wspomnianej Światowej Organizacji Zdrowia (WHO) zasadniczym celem polityki zdrowotnej wobec osób podeszłych jest wczesne wykrywanie i zapobieganie problemom zdrowotnym, promocja zdrowia w zakresie utrzymania i poprawy sprawności psycho-fizycznej, a także szereg działań edukacyjnych w zakresie profilaktyki i funkcjonowania seniorów na różnych poziomach życia społecznego.

\section{Funkcjonowanie społeczne seniorów}

Współczesny senior ma przed sobą wiele lat życia. W ciagu życia człowiek żyje w określonych grupach społecznych i pełni w nich różne role. Jedna z najważniejszych, a zarazem długotrwałych struktur jest rodzina. Nie sposób mówić o sytuacji osób starszych bez odwołania się do relacji z najbliższymi. Starość jest okresem, w którym zwiększa się wartość rodziny i relacji pomiędzy jej członkami. Jest to spowodowane wycofywaniem się człowieka starszego z aktywnego do tej pory życia zawodowego i pełnienia w życiu społecznym różnych ról. Seniorzy często jakość życia utożsamiaja z wyrazem poczucia przynależności do najważniejszej grupy społecznej, jaka jest rodzina. Zadowolenie z życia w różnych okresach starości wynika przede wszystkim z zakresu i jakości więzi łączących seniora z najbliższymi członkami rodziny lub innymi bliskimi mu ludźmi. Ograniczenie kontaktów i ról społecznych w związku z przejściem na emeryture czy stanem zdrowia sprawia, że wzrasta potrzeba podtrzymywania kontaktów z najbliższymi (Szatur-Jaworska 2000). Mówiąc o sytuacji rodzinnej osób starszych, należy zwrócić uwagę na rodzaj więzi łączących seniora z rodzina. Więź łącząca każdą rodzinę nie jest jednakowa, zmienia się w poszczególnych fazach życia rodziny czy różnych okolicznościach. Wobec czego niektóre z rodzin charakteryzuje wysoki stopień skonsolidowania - z socjologicznego punktu widzenia są atrakcyjne dla swoich członków, natomiast innym brakuje tej właściwości. L. Dyczewski wyróżnił trzy rodzaje więzi rodzinnej:

- więź strukturalno-przedmiotowa: stosunki między członkami rodziny a pokoleniami opierają się na podziale ról. Zakres pełnionych ról skupia się wokół utrzymywania i prowadzenia gospodarstwa domowego, opieki nad dziećmi i wnukami, podstawą jest wspólne zamieszkiwanie; 
- więź osobowa: stanowi jedną z najważniejszych więzi według Dyczewskiego. Bazą stosunków między rodzinami i pokoleniami jest sfera emocjonalno-wolitywna, niemożliwa do osiagnięcia w innych instytucjach, np.: szkole, zakładzie pracy, gdzie wzajemne postawy sa często nacechowane wrogością i rywalizacją;

- więź kulturowa: relacje miedzy członkami rodziny a pokoleniami określa zgodność postaw czy ich brak. Dotyczą one wspólnych bądź odmiennych wartości, wzorów zachowań, norm, zwyczajów czy faktów kulturowych. Rozbudowana treść więzi kulturowej ma wpływa na trwałość i jakość relacji międzypokoleniowej, która jest istotnym wyznacznikiem poczucia jakości życia u osób starszych (Dyczewski 2002:15).

Silne więzi z rodziną daja seniorowi poczucie bezpieczeństwa, umożliwiają zaspokajanie emocjonalnych potrzeb oraz wsparcie w sytuacjach kryzysowych takich jak: choroba, niepełnosprawność czy śmierć współmałżonka. Bliskie i znaczące więzi z innymi ludźmi stanowią swoistą bazę, która umożliwia zachowanie zdrowia fizycznego i psychicznego, przyspiesza proces rekonwalescencji, pozwala łatwiej radzić sobie ze stresem.

Zarówno w obecnych czasach, jak w przeszłości pomoc i opieka rodziny nad osobami starszymi są traktowane jako powinność. Stosunki pomiędzy członkami rodziny, a osobami starszymi powinno się postrzegać jako wymianę wzajemnych doświadczeń między pokoleniami, zwana „prywatnym transferem międzypokoleniowym” (Szukalski 2002:40). Dla wielu starszych osób czynnikiem determinującym poczucie zadowolenia z życia jest koncentracja na życiu domowym i sprawowanie roli rodzica, babci, dziadka czy kogoś bliskiego dla innych. W rodzinie istnieja silne związki pokoleniowe oparte na wzajemnej wymianie i opiece. Wymiana ta ma charakter materialny i niematerialny w postaci wartości emocjonalnych. Osoby starsze postrzega się w kontekście realizowania funkcji zabezpieczającej i opiekuńczej rodziny. Z jednej strony jest to pomoc udzielana przez członków rodziny na rzecz osób starszych, z drugiej - uczestnictwo dziadków w wypełnianiu zadań opiekuńczych i wychowawczych wobec młodej generacji (Balcerzak-Paradowska 2004:67). Wysiłek związany z wychowywaniem dzieci przez rodziców zazwyczaj pracujacych, często jest podejmowany przez nieaktywnych zawodowo dziadków. Zdolność osób do sprawowania funkcji opiekuńczej wobec wnuków zależy od wielu czynników, takich jak: sprawność fizyczna i intelektualna, sposób funkcjonowania i miejsce w strukturze rodziny, wymiar, jakość i forma spędzania czasu z wnukami (Steuden 2011:129). Osoby starsze nie żałują wszelkich środków i czasu, który poświęcają swoim wnukom, ponieważ one stanowią dla nich źródło satysfakcji, 
chęci do życia, poszerzają poprzez kontakty z nimi sferę intelektualna i emocjonalną. Możliwość częstego kontaktu i pomoc w opiece nad wnukami stanowi dla starszego człowieka źródło satysfakcji i zadowolenia, co jednocześnie wyzwala w nim nowe pokłady aktywności, zarówno fizycznej, jak i psychicznej. Zmniejsza ryzyko izolacji społecznej i emocjonalnej, zapobiega objawom depresyjnym, a także zapewnia poczucie bliskości, bycia potrzebnym, wzmaga poczucie własnej wartości i sensu życia. Wraz z upływem lat zmienia się charakter relacji pomiędzy dziadkami i wnukami. Następuje zamiana ról między pokoleniami, także w zakresie sprawowania opieki i udzielania wsparcia. Okoliczności te prowadzą do umacniania więzi międzypokoleniowej, a także wchodzenia w nowe role zarówno dziadków, jak i wnuków. Ze względu fakt, iż jesteśmy społeczeństwem starzejącym się, postawy i relacje między dziadkami a wnukami powinny prowadzić do kształtowania się i wypracowania prawidłowych wzorców współpracy międzypokoleniowej. Pozytywne relacje z bliskimi sa ważne dla dobrostanu osób starszych, zwłaszcza wobec rosnacego ryzyka zachorowania na choroby przewlekle, ewentualna niepełnosprawność, zniedołężnienie i poczucie osamotnienia. Wiele rodzin nadal prowadzi wspólne gospodarstwo domowe, stwarza to możliwość codziennych kontaktów i aktywnego uczestnictwa $\mathrm{w}$ rodzinie wielopokoleniowej. Osoby starsze majace pozytywne relacje z najbliższymi są na ogół bardziej zadowolone z życia i wykazuja wyższy poziom satysfakcji życiowej, która współwystępuje z pozytywna ocena jakości życia. Prawidłowe relacje osoby starszej z pozostałymi członkami rodziny sa kluczowa kwestią związana z pozytywnym funkcjonowaniem w pozostałych wymiarach życia społecznego.

\section{Aktywność a jakość życia}

W rozważaniach nad jakościa życia u osób starszych podkreśla się również znaczenie aktywności człowieka w wielu jej aspektach. Teorie adaptacji do starości zakładaja, że jest to okres, który umożliwia seniorom utrzymanie dotychczasowej, a nawet pogłębianie aktywności w życiu rodzinnym, społecznym i niekiedy zawodowym, a także podnoszenia jakości życia związanej z poczuciem jego sensu (Steuden 2011:87). Wzrost aktywności przyczynia się do poprawy samopoczucia człowieka, poprawy samooceny, obniża lęk, pomaga w akceptacji tej fazy życia, a także prowadzi do zwiększenia częstotliwości i intensywności kontaktów interpersonalnych. Aktywność jest ważna na każdym etapie życia jednostki. Jednak w przypadku starości ma znaczenie szczególne, bowiem w sposób istotny wpływa na zadowolenie i kondycję człowieka. 
Aktywność to synonim życia, stały i dostosowany do możliwości danej osoby wysiłek (Dyczewski 1994:33). Jest on warunkiem prawidłowego rozwoju, umożliwia prowadzenie twórczego i harmonijnego życia, jest podstawa leczenia wielu chorób, opóźnia procesy starzenia się. W szerokim zakresie aktywność w każdej fazie rozwoju obejmuje rozwijanie osobowości, zwiększanie wiary we własne siły, poszerzanie horyzontów myślowych. Elementy te maja wpływ na budowanie korzystnego obrazu samego siebie, a w konsekwencji lepszego radzenia sobie ze wszelkimi problemami, jakie pojawiaja się w życiu. Osoba aktywna w sytuacji kryzysowej nie zamyka się w sobie, przyjmuje postawę gotowa do działania. W rozwijaniu takiej postawy ważna rolę odgrywaja takie czynniki, jak: typ osobowości, stan zdrowia, sytuacja rodzinna, materialna, wykształcenie, dostęp do instytucji kulturalnych. Aktywność jest naturalną i powracająca potrzebą człowieka, decydującą o współistnieniu w danym środowisku. Jej przeciwieństwem jest bierność, która utożsamiana jest na ogół z choroba, niepełnosprawnością, zakłóceniami w relacjach międzyludzkich.

Aktywna postawa osób w wieku starszym jest uważana za wręcz niezbędna dla poczucia jakości życia w tym okresie. Pojęcie aktywności nie oznacza tylko fizycznej sprawności czy też możliwości wykonywania pracy zawodowej, ale czynny udział w życiu społecznym, ekonomicznym, kulturalnym, duchowym i rodzinnym. Zwraca się uwage, że w przypadku osób starszych duże znaczenie ma aktywność fizyczna i towarzyska. Systematyczna aktywność ruchowa to jeden z najistotniejszych czynników niwelujących upływ czasu, ułatwiający pozytywne starzenie się. Prowadzenie aktywnego trybu życia zmniejsza ryzyko złamań, stłuczeń, upadków, nadciśnienia, chorób serca, zawału, osteoporozy, cukrzycy, a w konsekwencji przedwczesnej śmierci. Ta forma aktywności oferuje poczucie odprężenia, poprawę zdrowia fizycznego, zwiększenie mobilności organizmu, relaks, niwelowanie stresu, podnosi jakość życia seniora. A. Zych podkreśla, że zachowanie optymalnej równowagi pomiędzy aktywnościa psychiczną i fizyczną człowieka jest nie tylko podstawą dobrego zdrowia i długowieczności, ale również swoista gwarancją łagodnego wejścia w tę ostatnią fazę życia człowieka (Zych 1999:100-101).

Aktywność przybierająca różne formy, ma istotne znaczenie również w eliminowaniu postępującego marginalizowania osób starszych we współczesnej kulturze i społeczeństwie. Próbą zatrzymania tego negatywnego procesu sa działania majace na celu aktywizowanie samych seniorów. Obojętna postawa względem otoczenia, wycofanie się z życia, zmniejszanie własnej aktywności wzmacnia poczucie bezużyteczności i osamotnienia. Działania na rzecz seniorów takie, jak np.: 
działalność Uniwersytetów Trzeciego Wieku, Centrów Aktywności Seniora, wolontariat maja na celu inspirowanie ich do podejmowania własnych inicjatyw, ale przede wszystkim priorytetowym założeniem jest przeciwdziałanie ich społecznej marginalizacji i izolacji społecznej. Uczestnictwo osób starszych w tego typu projektach aktywizujących, kształtuje ich postawy prospołeczne, prozdrowotne, mobilizuje do wzajemnej pomocy, również międzypokoleniowej. Starania te sprzyjaja podtrzymaniu jakości życia poprzez próbe zaspokojenia potrzeb osób w wieku podeszłym, głównie dotyczacych bezpieczeństwa, przynależności do grupy i zajmowanego w niej określonego miejsca, bycia użytecznym. Podkreślenie znaczenia potrzeby bezpieczeństwa wobec najstarszej grupy wiekowej wydaje się niezwykle istotne, gdyż - jak twierdzi L. Frackiewicz potrzeba ta stanowi podstawowy element jakości życia (Frąckiewicz 1985:144).

\section{Podsumowanie}

Problem jakości życia osób starszych obejmuje wiele kontekstów zagadnień z związanych z medycznymi, społecznymi, ekonomicznymi wymiarami funkcjonowania tej grupy społecznej. Ocena jakości życia seniorów stała się znakiem zachodzacych przemian procesów cywilizacyjnych i przedmiotem ożywionego dyskursu społecznego. Zmienia się podejście do postrzegania osób starych w społeczeństwie, postulowane są różne systemy ewaluacji jakości życia seniorów. Podnoszenie standardu funkcjonowania życia ludzi starszych stało się kluczowym elementem polityki społecznej i zdrowotnej wielu podmiotów odpowiedzialnych za jakość i poziom życia swoich obywateli. Termin jakości życia może być rozpatrywany w wielu kontekstach. Podstawowymi determinantami dobrego samopoczucia fizycznego, psychicznego i społecznego w sytuacji osób starszych są niewątpliwie pozytywne relacje z najbliższymi, zadowalający stan zdrowia i usług medycznych, a także szeroki zakres aktywności życiowej seniorów, przejawiający się w wielu płaszczyznach życia społecznego, kulturalnego czy politycznego.

O jakości życia ludzi starszych generalnie decydują takie czynniki jak (Trafiałek 2002:323-326): model polityki społecznej (system dystrybucji świadczeń emerytalnych i redystrybucji świadczeń socjalnych); sprawność biologiczna, mobilność ludzi przechodzacych na emeryture;; sieć, funkcjonalność i dostępność placówek opiekuńczych, dostęp do opieki; aktywność; społeczny stereotyp starości i poczucie odpowiedzialności za własna starość; otwarcie środowiska lokalnego na potrzeby ludzi w starszym wieku. 


\section{Bibliografia}

Balcerzak-Paradowska B. (2004), Rodzina i polityka rodzinna na przetomie wieków, IPiSS, Warszawa.

Czarnecka K. (2004), Wybrane aspekty opieki nad starzejacym sie społeczeństwem, „Zdrowie i Zarządzanie”, nr 6, s. 44-47.

de Walden-Gałuszko K. (1994), Jakość życia - rozważania ogólne. [w:] K. de WaldenGałuszko, M. Majkowicz, Jakość życia w chorobie nowotworowej, Wydawnictwo Uniwersytetu Gdańskiego, Gdańsk.

Dyczewski L. (1994), Ludzie starzy i starość w społeczeństwie i kulturze, Redakcja Wydawnictw Katolickiego Uniwersytetu Lubelskiego, Lublin.

Dyczewski L. (2002), Więź między pokoleniami w rodzinie, Towarzystwo Naukowe Katolickiego Uniwersytetu Lubelskiego, Lublin.

Frąckiewicz L. (1985), Karta praw człowieka starego, Instytut Wydawniczy Związków Zawodowych, Warszawa.

Frąckiewicz L. ( red.) (2002), Proces starzenia się ludności i jego społeczne konsekwencje, Wydawnictwo Śląskie, Katowice.

Halicka M., Pędlich W. (2002), Satysfakcja życiowa ludzi starych. [w:] B. Synak (red.), Polska starość, Wydawnictwo Uniwersytetu Gdańskiego, Gdańsk.

Szukalski P. (2010), Jakość życia seniorów XXI wieku. Ku aktywności, Wydawnictwo Biblioteka, Łódź.

Krzyżkowski J. (2004), Psychogeriatria, Warszawa.

Lasota L. (2006), Satysfakcja z życia emerytów $w$ Polsce i $w$ Niemczech. [w:] S. Steuden, M. Marczuk (red.), Starzenie się a satysfakcja z życia, Wydawnictwo Katolickiego Uniwersytetu Lubelskiego, Lublin.

Mielczarek A. (2010), Człowiek stary $w$ domu pomocy społecznej. Z perspektywy polityki społecznej i pracy socjalnej, Wydawnictwo Akapit, Torun.

Orzechowska G. (1999), Aktualne problemy gerontologii społecznej, Wydawnictwo WSP, Olsztyn.

Sęk H. (2001), Wprowadzenie do psychologii klinicznej, Wydawnictwo Naukowe Scholar, Warszawa.

Steuden S. (2011), Psychologia starzenia i starości, Wydawnictwo Naukowe PWN, Warszawa.

Steuden S., Okła W. (2007), Jakość życia w chorobie, Wydawnictwo Katolickiego Uniwersytetu Lubelskiego, Lublin.

Steuden S., Oleś P. (2005), Oddziaływania zwiększajace poczucie jakości życia u pacjentów z zaburzeniami widzenia. [w:] A. Bańka (red.), Psychologia jakości życia, Stowarzyszenie Psychologia i Architektura, Poznań.

Straś-Romanowska M. (2005), Jakość życia w świetle założeń psychologii zorientowanej na osobe, „Kolokwia Psychologiczne”, tom 13, s. 117-120.

Szatur-Jaworska B. (2000), Ludzie starzy i starość w polityce spotecznej, Oficyna Wydawnicza Aspra-In, Warszawa.

Szatur-Jaworska B., Błędowski P., Dzięgielewska M. (2006), Podstawy gerontologii spotecznej, Oficyna Wydawnicza Aspra-In, Warszawa.

Szukalski P., (2002), Przeptywy międzypokoleniowe $i$ ich kontekst demograficzny, Wydawnictwo Uniwersytetu Łódzkiego, Łódź.

Talarska D., Wieczorowska-Tobis K., Szwałkiewicz E. (2007), Opieka nad osobami przewlekle chorymi, $w$ wieku podeszłym i niesamodzielnymi. Podręcznik dla opiekunów medycznych, Wydawnictwo Lekarskie PZWL, Warszawa. 
Tobiasz-Adamczyk B. (2000), Wybrane elementy socjologii zdrowia $i$ choroby, Wydawnictwo Uniwersytetu Jagiellońskiego, Kraków.

Trafiałek E. (2002), Jakość przedtużonego życia, [w:] K. Frysztacki, Wartości i normy społeczne - wokót uwarunkowań i czynników pracy socjalnej, Instytut Socjologii Uniwersytetu Jagiellońskiego, Kraków.

Wolańska D. (2006), Jakość życia starszych mieszkańców Dolnego Ślaska, [w:] J.T. Kowalski, P. Szukalski, Starość $i$ starzenie sie jako doświadczanie jednostek i zbiorowości ludzkich, Zakład Demografii Uniwersytetu Łódzkiego, Łódź.

Woźniak Z. (2003), Priorytety w programach gerontologicznych organizacji międzynarodowych $i$ struktur europejskich jako przestanka budowy polityki społecznej wobec starości i osób starszych, [w:] Starzenie się społeczeństwa wyzwaniem dla polityki społecznej, Materiały konferencyjne ROPS w Krakowie, Kraków.

Zych A.A. (1999), Człowiek wobec starości szkice z gerontologii społecznej, Wydawnictwo Ślaskie, Katowice.

Zych A. ( 2007), Leksykon gerontologii, Oficyna Wydawnicza, Impuls, Kraków.

\section{Selected contexts of the quality of life of the elderly}

The process of population ageing is a demographic phenomenon of an intensity and scale previously unseen, which spreads over almost all the European countries and other highly developed societies of the world. The extension of lifespan caused mainly by the advance of medicine and the economic development increased interest in the old age in the cultural, economic and social aspect. The fact of the society getting old is related to numerous social, medical, cultural and economic consequences. Old age and its aspects is strongly connected with the socio-ecological model of health, the purpose of which is the global evaluation of the quality of life combining medical, psychosocial and cultural consequences of growing old. This study attempts to describe the issue of the quality of life of the elderly paying special attention to health and the social functioning of senior citizens.

Key words: the quality of life, health, old age, consequences, needs. 